Article

\title{
An Integrated Rural Development Mode Based on a Tourism-Oriented Approach: Exploring the Beautiful Village Project in China
}

\author{
Chunliu Gao ${ }^{1,2}$, Li Cheng ${ }^{1,2, *}$, Javed Iqbal ${ }^{3}$ and Deqiang Cheng ${ }^{4,5}(\mathbb{D}$ \\ 1 Tourism School, Sichuan University, Chengdu 610064, China \\ 2 International Laboratory for Interdisciplinary Tourism \& Heritage Research, Sichuan University, \\ Chengdu 610041, China \\ 3 Department of Earth Sciences, Abbottabad University of Science and Technology, Abbottabad 22010, Pakistan \\ 4 Key Laboratory of Mountain Hazards and Earth Surface Process, Institute of Mountain Hazards and \\ Environment, Chinese Academy of Sciences, Chengdu 610041, China \\ 5 College of Resources and Environment, University of Chinese Academy of Sciences, Beijing 100049, China \\ * Correspondence: chengli@scu.edu.cn; Tel.: +86-28-85470016
}

Received: 13 June 2019; Accepted: 15 July 2019; Published: 17 July 2019

\begin{abstract}
To solve the decline of rural development, an effective development mode is indispensable. Rural tourism is a key approach in poverty alleviation and rural revitalization in China. The comparative analysis of the 50 most beautiful villages as awarded by the Ministry of Agriculture of China shows that the rural tourism development mode with the integration of production, village and scenery realizes the sustainable development of rural areas. To examine this further, this study takes Qinggangshu Village as a case study and constructs a systematic rural tourism-based sustainable development model called Aims, Measures, Demands (AMD). The results show that Qinggangshu Village has changed from a single farming village to a mature tourism village due to the Beautiful Village Project's support. In this process, the production, village and scenery have made great change by promoting rural tourism development. Land consolidation and land asset activation is at the core of rural transformation and development, which can drive the reorganization and flow of labor and capital and can also make rebuilt villages more comfortable living spaces. Furthermore, a good landscape environment can stimulate development and competition. This study could be used as an example of attaining sustainable development for other rural areas.
\end{abstract}

Keywords: sustainable development; AMD development model; production; village; scenery; Qinggangshu Village; rural revitalization

\section{Introduction}

As non-urbanized areas, rural areas have unique resources, not only as containers of traditional culture, but also as comprehensive carriers of society, economy and landscape. The development of rural areas presents staged features with the improvement of social productivity. With the continuous urban expansion and impact of industrialization, the development of rural areas has generally experienced the process of "development, stability, and recession" [1-5].

In light of this development status, Britain, Japan and South Korea have each adopted different measures to cope with the decline of rural areas. Among them, the British government formulated a series of agricultural development policies from the 1940s to the 1970s [6]. These measures contained a unified plan for the development of villages in the form of laws that effectively relieved the contradiction of the land annexation at that time. In the early 1940s, the shortage of materials caused by the industrial revolution, World War II and the previous trade deficit led to a growing demand 
for domestic agricultural products in Britain $[7,8]$. In this context, Britain's first act on agricultural development was enacted in 1947. The main objective of the Act was to promote the development of agriculture by guaranteeing the market stability of agricultural products, setting reasonable prices and increasing the labor force engaged in agricultural production [9]. In 1957, the government adjusted its policy and promulgated a new agricultural act, which aimed at the government's excessive intervention in the agricultural market and the unbalanced structure of agricultural products, and promised to ensure the price stability of agricultural products [10]. In the 1960s, Britain's agricultural development policy was mainly reflected in its concern for the scale and marketization of agriculture, and clearly encouraged the merger of small farms and the expansion of agricultural market [11]. In the 1970s, global competition and counter-urbanization brought new opportunities to rural development, yet the existing rural development strategies could no longer meet development needs. However, a turning point was when Britain joined the European Community in 1973. Agricultural development within Britain started to be influenced by the agricultural development policy formulated by the European Community [12]. The policy gave lessees better protection and more stable rights to demand higher agricultural productivity, maintain reasonable agricultural prices and establish effective common prices for agricultural products [13].

The Japanese economy was also severely damaged from the impact of World War II. Rural labor, the environment, and the economy were all destroyed [14]. Facing a tough situation, the Japanese government launched the "Rural Revitalization movement" in the 1970s [15-17]. In this movement, the government promoted the development of local characteristics by supporting the industry named "One Village One Product" [18-20]. The choice of rural products was decided by the villagers depending on local resources. The government provided guidance to the farmers in the technologies, production, market and intellectual support. From the beginning of the 1970s to the early 21st century, the rural environment in South Korea was abominable. South Korea carried out "new village construction" in three stages, namely "infrastructure construction, industry promotion, and culture remolding", in the rural areas according to different characteristics of rural development in different places [21,22].

There are some similarities in the context of rural revitalization movements occurring in Britain, Japan and South Korea. Britain's non-agricultural industry, Japan's “One Village One Product" and South Korea's modern agriculture were all measures to solve the problem of backward development of rural areas in the context of urbanization. In various development stages, the function of rural areas could be different, but their essential responsibilities have an inherent consistency [23], which is to provide the basic production material for urban development, to meet the internal demand of the production, and for the improvement of life for the residents in the villages.

At present, rural development in China means gradual change into a modern village, as western developed countries have done. The rural revitalization of China is the target of rural development in the context of rapid urbanization [24]. Liu put forward the "four priority" strategy of rural development, and considers that rural revitalization is an important link in the process of global urbanization [25]. Through studying the strategy of rural revitalization, Zhu believes that rural space structure and production relations nurture rural culture, so the revitalization of the countryside is not only the optimization of the material production environment, but also integrated development based on rural cultural value [26]. He believes that rural revitalization is the integrated development of "production, village and scenery", which can effectively cope with the present problems of rural hollowing and agricultural decline in China [27].

In the context of rapid urbanization, rural areas face the problem of insufficient pillar industries, hollow villages and land abandonment. A reasonable and effective rural development mode is irreplaceable in promoting rural sustainable development. In 2013, the Ministry of Agriculture launched "the Beautiful Village Project" to promote these rural areas. Since then, "the Beautiful Village Project" has become the main approach to realize rural revitalization in China.

In China, more and more traditional villages have achieved rural revitalization through promoting the comprehensive development of "production, life and ecology" [28] to construct beautiful 
villages [29]. Beautiful village construction has changed the traditional agricultural production structure, rural planning and layout, as well as rural culture and ecological environment. The development of "production, life and ecology" during the construction of beautiful villages is equivalent to the integrated development of "production, village, and scenery" in which the "village and scenery" are the substantiation expression of the abstract conception of "life and ecology" [27]. The integration development of "production, village and scenery" [30] is an important theory when constructing beautiful villages in order to realize rural revitalization. Millions of different villages in China still require the knowledge of how to implement rural revitalization. In modern times, rural tourism has become an important driving force in improving the ecological environment and speeding up poverty alleviation.

Consequently, rural areas are no longer ordinary villages, but have become a region of tourism value and market significance. Rural tourism has become the driving force of rural sustainable development by displaying agricultural culture, ecology, agricultural activities and traditional culture, thus attracting the aspiration of urban residents. How did the development of these ordinary villages come true? What is the operational logic behind the process of change? Can it act as a reference for other villages? Through the analysis of the 50 most beautiful villages in China and the case study of Qinggangshu Village, this paper attempts to discover the linking factors and explore rural sustainable development experiences based on rural tourism.

\section{Research Methodology}

This study was carried out using two different scales. Firstly, the 50 most beautiful villages were collected, as chosen by the Ministry of Agriculture of China from 2013 to 2017. The characteristics of spatial distribution and rural industrial spatial distribution were analyzed by using zoning statistics and the kernel density analysis method [31,32]. On this basis, an integrated rural tourism development mode of "the Beautiful Village Project" was summarized. In order to gain a deeper understanding of this mode, we chose Qinggangshu Village as a small-scale case study. Remote sensing images from Google Earth [33,34], in 2002, 2010, 2014 and 2017, were used in order to show the change in land use. Intensive and meticulous field surveys were undertaken in this village to collect useful data such as that of the environment and the impact from the tourism industry development. We verified this integrated rural development mode with the help of the Aims, Measures and Demands (AMD) development model [35].

\section{Fifty Most Beautiful Villages in China}

\subsection{Spatial Distribution Verified by the Ministry of Agriculture}

To tackle the issues of land abandonment, hollowing out, labor loss, slow economic development and other overall decline issues faced in rural areas, the Chinese government proposed a nationwide Beautiful Village Project in 2013. The Beautiful Village Project covers rural planning, rural culture, ecological environment and economic development. Beautiful Village construction is an important part of Beautiful China construction [36] and is also a significant way to realize rural revitalization [37]. Since then, the effort to revitalize villages has received national attention. The project is a comprehensive rural development strategy, leading to a new "rural reconstruction" mode with ecological construction, environmental protection and comprehensive renovation at its core.

With the continuous advancement of the project, the original rural community landscape and its traditional social relations and culture have gradually changed. Under the construction goal of the beautiful countryside, rural areas have undergone drastic changes [38]. Since 2013, the Ministry of Agriculture has begun to select 10 successful beautiful villages every year and named them "the most beautiful village". Their selection criteria include fine natural ecology, happy life, harmonious culture and innovative leadership. By the end of 2017, a total of 50 China's most beautiful villages had been selected out (Figure 1) [39]. 


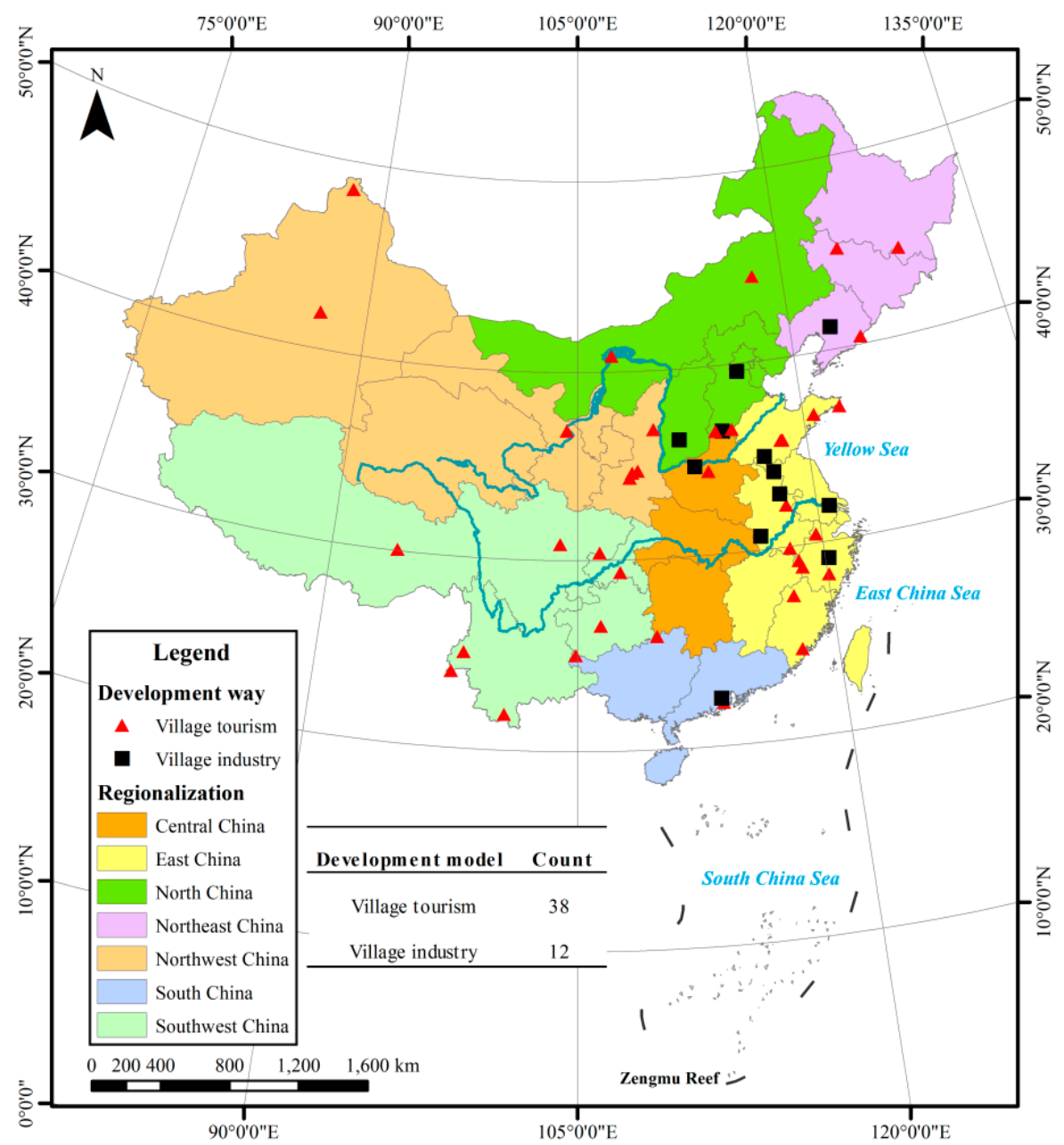

Figure 1. Distribution and development ways of the most beautiful villages in China.

From the location of these villages as released by the government, we found their detailed coordinate information on Google Map, imported them into ArcGIS software, added relevant attributes, and established a spatial database.

\subsection{Analysis of Spatial Distribution Characteristics}

\subsubsection{Spatial Distribution Characteristics}

According to Figure 1, the number of the most beautiful villages, as verified by the Ministry of Agriculture, varies greatly within the various geographical regions of China. East China has been awarded more villages than other regions. Figure $2 \mathrm{a}$ shows the relationship between the number of villages and the area in different regions. A larger area does not mean that it can have more villages chosen for the most beautiful village, for example Northwest China which has vast land, but a poor living environment. It can be shown that the most beautiful villages are inhomogeneous within geographical distribution.

On the other hand, the relationship between gross domestic product (GDP) and the count of villages reflects that regional economy plays an important role in promoting the construction of beautiful villages (Figure 2b). East China has been able to select so many beautiful villages because of its strong economic base, which has played an important role in supporting the construction of the villages. At the same time, the region that contains a high number of beautiful villages and generally has a better living environment. 

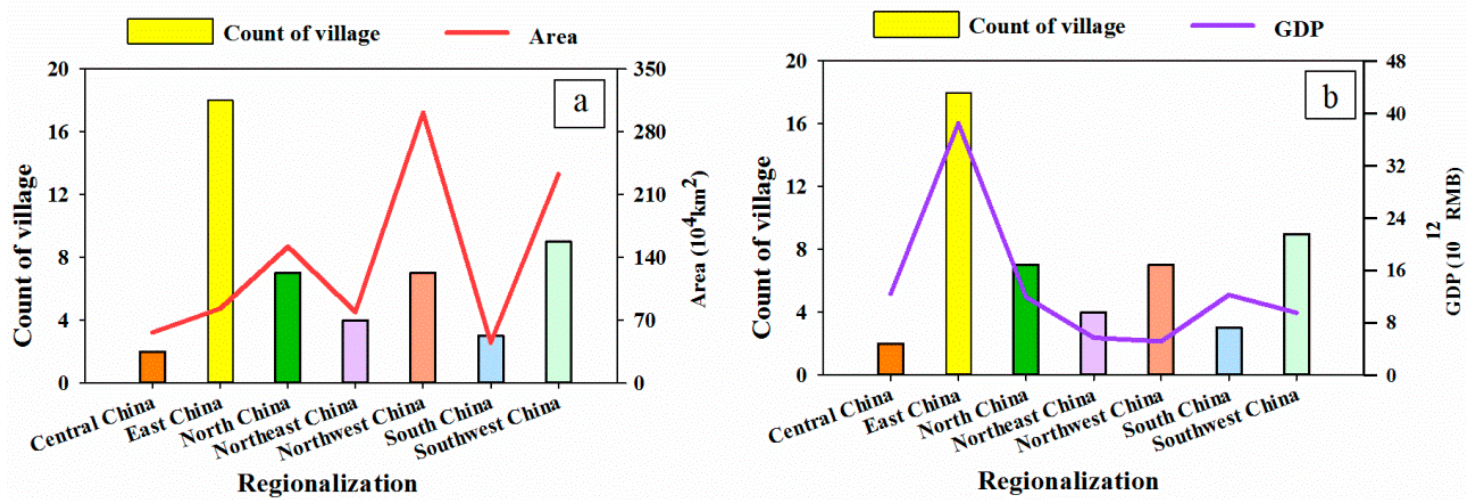

Figure 2. Characteristics of the 50 most beautiful villages: (a) Relationship between the count of villages and the area of regionalization; (b) Relationship between the count of villages and the GDP of regionalization.

\subsubsection{Rural Industrial Spatial Distribution}

The 50 most beautiful villages have different development ways. According to the analysis of each village's development condition, two main development ways or modes of these villages were summarized. These include village tourism and village industry, which develops rural areas through village-run factories (Figure 1). By comparing the count of these two development modes, village tourism villages make up the majority $(76 \%)$. We used ArcGIS software to analyze the kernel density of two rural development ways. It could be seen that beautiful villages based on village industry are mainly distributed in the eastern region of China (Figure 3b). The development of the most beautiful villages in the western regions of China is mainly supported by village tourism (Figure 3a).
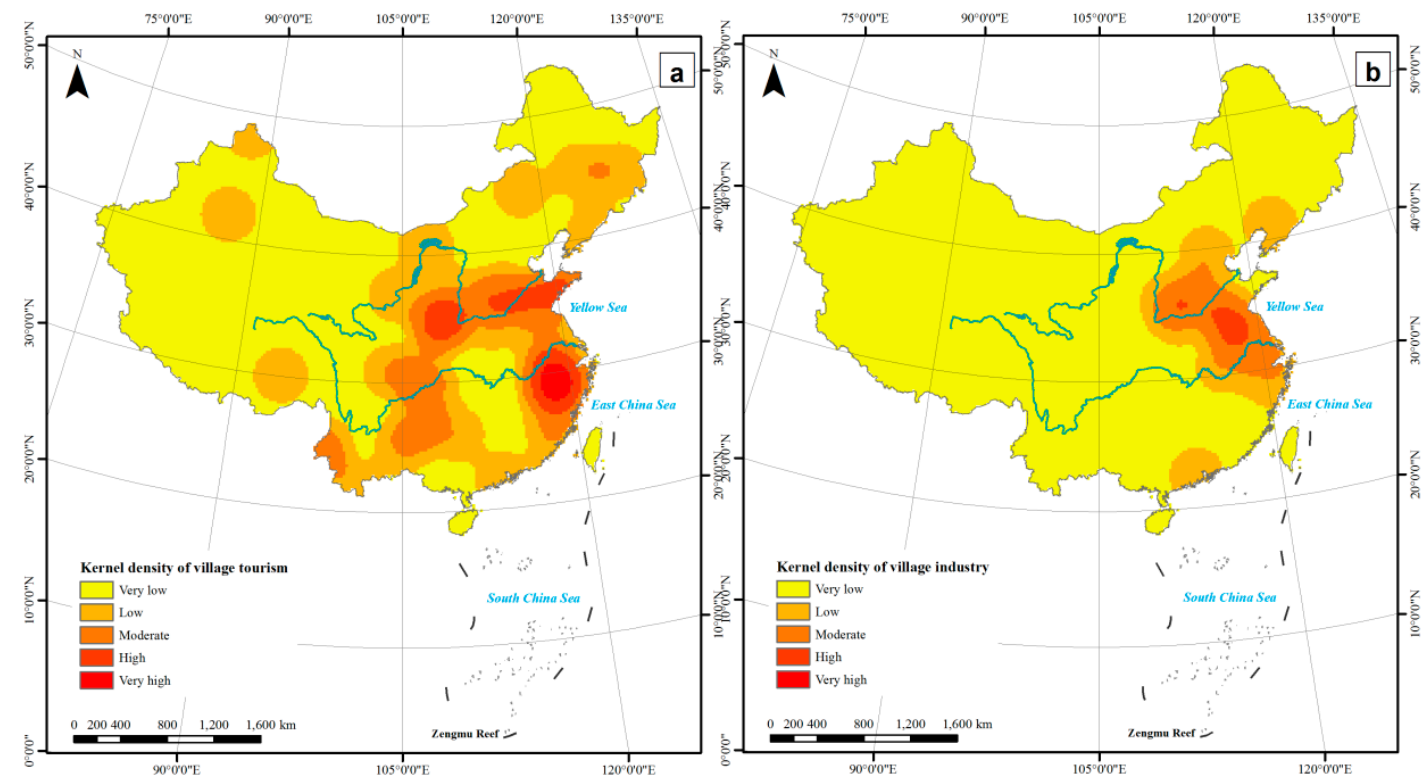

Figure 3. Kernel density analysis: (a) Village tourism; (b) Village industry.

The vast western regions of China have a good original ecological environment and many characteristic villages, which has become an important condition for the development of rural tourism (Figure 4). Compared with the construction of 50 beautiful villages through developing the village industry, village tourism is an important and effective mode to construct beautiful villages and realize rural revitalization, and it has the advantages of less investment, quick profit returns and good ecological protection. 

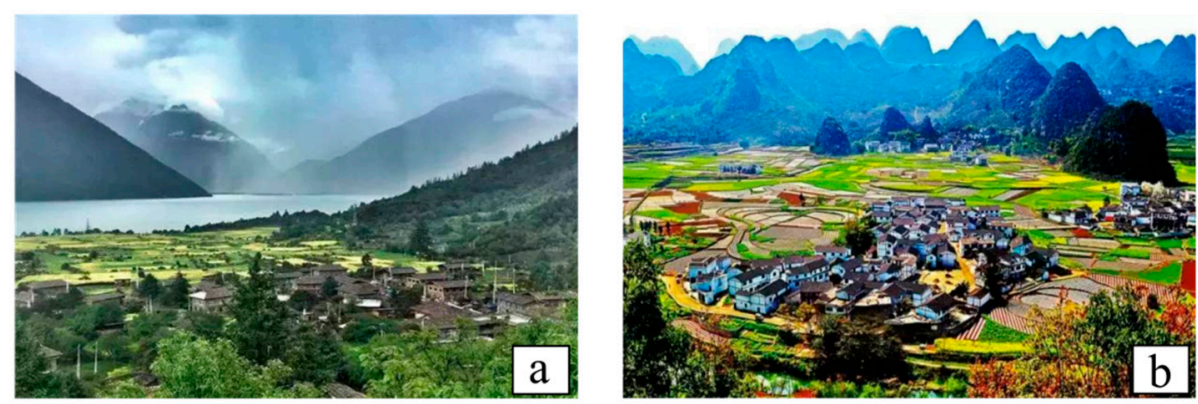

Figure 4. Beautiful natural environment of beautiful villages, (a) Cuogao Village, Tibet [40]; (b) Nahui Village, Guizhou [41].

\subsection{Integrated Rural Tourism-Oriented Development Mode}

With the development of the tourism market, rural tourism has become a new industrial growth point and mode to support the sustainable development of rural areas [42]. This mode is quite different from the traditional rural development mode, which puts forward higher requirements for the rural ecological environment. For the traditional development mode, the primary element or motive that supports the development of the regional economy is production. It could have an impact on the quality of living for villagers and landscapes. The promotion of production and landscape in the village is not absolute. In many cases, the income of the villagers has increased, but the living and surrounding ecological environment has not been improved. There are many "garbage" villages [43] in China that develop the economy by recycling and processing foreign garbage. Furthermore, recycling of foreign garbage has become a pillar of the industry in these regions. The practice of ignoring life and ecology for the purpose of developing an industry is a morbid state of affairs.

Generally, many rural material conditions are improved after a certain development of the rural economy. When the development of the rural industry makes the material need of the villagers satisfied, the villagers will have higher requirements for the quality of the surrounding living environment [44]. The rural scenery has the role of "display, absorption and fusion", which is of great practical significance to the sustainable development of the rural ecological civilization. The beautiful scenery satisfies the needs of the villagers' spiritual world and, as a tourist resource, it can bring income to the villagers.

It could be found that the above mentioned traditional rural development mode is slow to improve the quality of life for villagers and ignores the concept of human-centered development. Additionally, the rural scenery development is usually placed last, resulting in the lack of scenery protection in this process [45]. The independent development mode of "production" based on industrial priority can't fully solve the problems that arise under this new situation. In the 21st century, China's rural areas need to examine a new perspective considering the enhancement of China's national strength and the increase in investments in rural development. Under the background of rural revitalization, the new integrated development mode of "production, village and scenery" is not isolated [35], and it is a mutually promoting symbiotic system.

Rural tourism is a new attempt to extend modern tourism to traditional agriculture. Through the promotion of tourism, ecological agriculture and ecological tourism are organically integrated, resulting in a new type of industry. The development of tourism has brought in an influx of tourists, changed the original social structure of the countryside, and brought about new social relations and social contacts [46]. At the same time, it has promoted the development of transportation, catering and hotels, provided employment opportunities, changed the traditional agricultural production structure, made full use of the surplus labor resources in the countryside, and effectively increased rural residents, especially tourists and merchants. It can be said that the impact of tourism on rural communities is reflected in the environment, political, economic, social and cultural aspects [47] (Figure 5). 


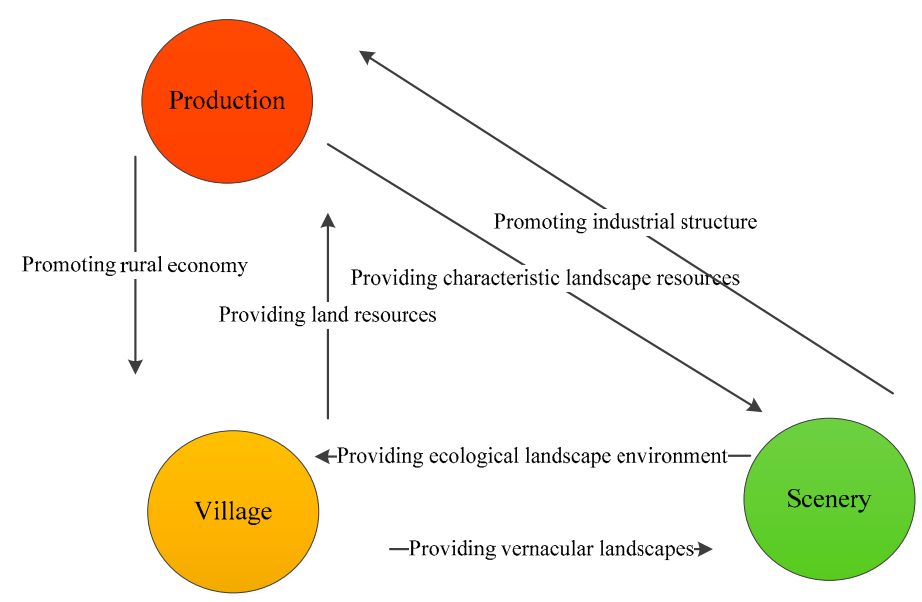

Figure 5. Integrated rural tourism-oriented development mode.

\section{Integrated Rural Tourism-Oriented Development Mode: Case Study in Qianganshu Village}

The integration development mode of "production, village and scenery" as based on rural tourism provides a new way of developing Chinese villages in the new century and helps to revitalize the countryside. In this mode, the development of rural areas, with village development as its core, in order to improve the quality of life of villagers, focuses on the integration with production and scenery in the initial stage of rural development. In this process, production and scenery can promote each other. It ultimately promotes the development of rural areas in order to improve the quality of life for the villagers. In the following sections, Qinggangshu Village would be taken as an example to introduce the village's integrated village tourism development of "producing, village and scenery" in order to enable people to better understand this development mode. Qinggangshu Village is a typical village affected by both beautiful rural strategy and tourism development. In 2015, Qinggangshu Village was appraised as one of "the most beautiful villages in China". The development of its beautiful rural space and tourism space has a certain representativeness in the background of rural development in China.

\subsection{Remote Sensing Images of Qinggangshu Village}

Qinggangshu Village is located between the Xuyan River and the Baitiao River in Sandaoyan Town, Pidu District, Chengdu, Sichuan [48]. There are 11 villager groups, 685 families and 2183 people in the village, covering an area of 1.8 square kilometers. Shaxi Road passes through the village from southeast to northwest, dividing Qinggangshu Village into two regions (Figure 6). Qinggangshu Village is a 20-min drive away from Chengdu, and is the nearest village of Sandaoyan Town to Chengdu. The Xuyan River and the Baitiao River are the source of the Fu River in Chengdu.

The ecological environment of Qinggangshu Village has the typical rural scenery in the west of Sichuan. Before 2012, the development of Qinggangshu Village depended on the traditional farming, and the living conditions were abominable. The village residents mostly worked in nearby or even farther manufactories, and rarely returned to the village, with only old people and children left in the village [48].

The remote sensing images of Qinggangshu Village were obtained and downloaded from Google Earth. The four images were obtained respectively on 3 September 2002 (Figure 7a), 15 November 2010 (Figure 7b), 11 November 2014 (Figure 7c) and 24 December 2017 (Figure 7d). The first two images are remote sensing images before the village was rebuilt in 2012, and the other two are remote sensing images after the rebuilding. By comparing the images of different periods, it can be seen that the roads of the village in 2017 were more orderly, the buildings were clustered, and the vegetation coverage had obviously increased in comparison with 2002 (Figure 7a,d). All of these benefits from the new rural planning and land arrangements, with the village beginning its transformation from traditional village to beautiful village since 2012 . 


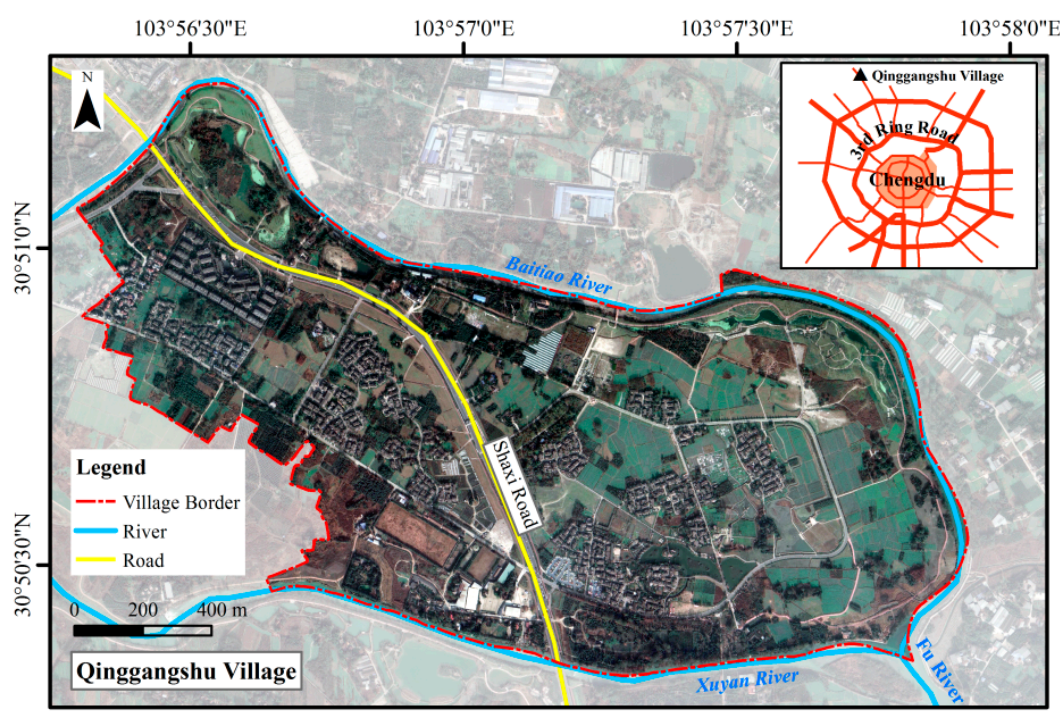

Figure 6. Location map of Qinggangshu Village.
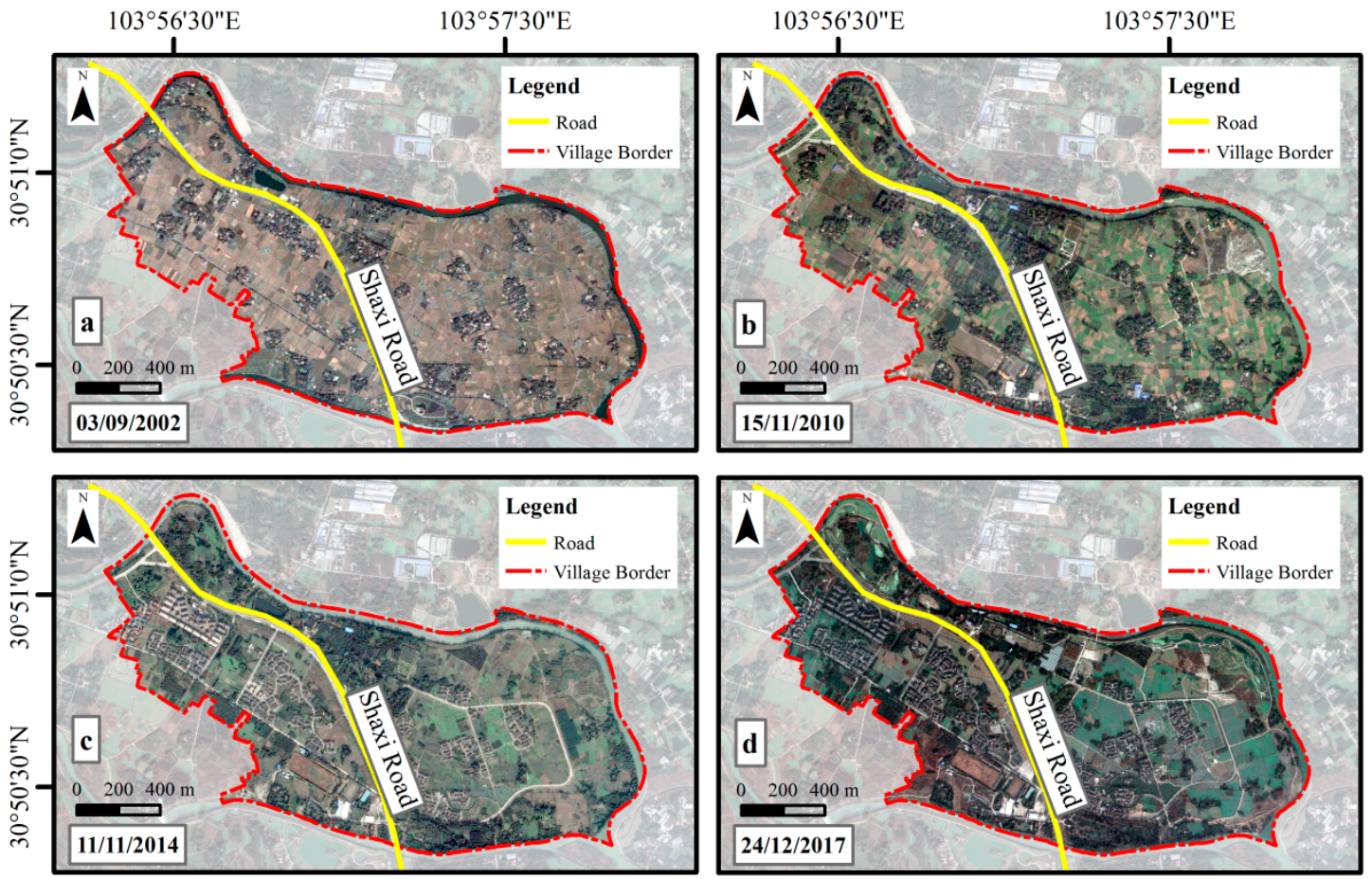

Figure 7. Remote sensing images of Qinggangshu Village during the period 2002-2017.

\subsection{Field Work in Qinggangshu Village}

Field research is an important way to acquire first-hand data. This research has been undertaken for one year in Qinggangshu Village, and abundant data including hundreds of photos and twenty questionnaires have been obtained. Figure 8 shows photos taken by the researchers when doing the investigation of Qinggangshu Village. 

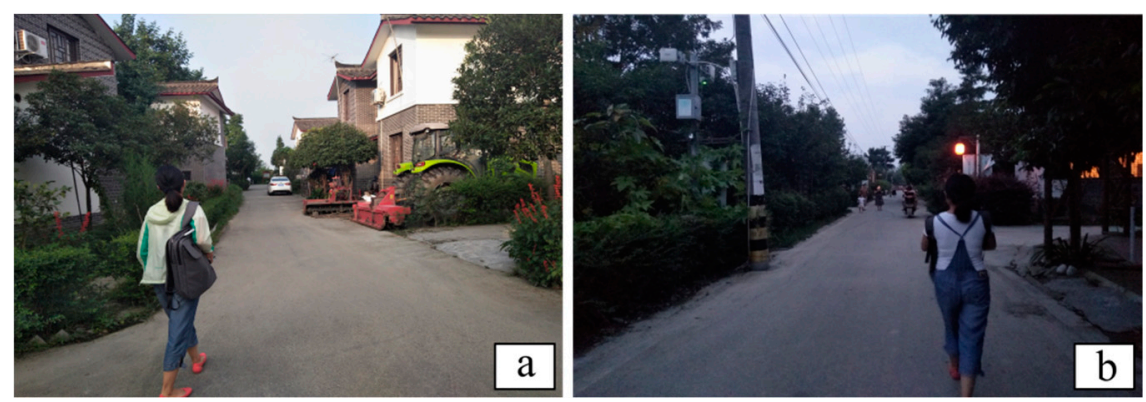

Figure 8. Survey photos of Qinggangshu Village, (a) New house; (b) New road.

\subsection{Findings}

\subsubsection{Dilemmas of the Traditional Rural Development Pattern of Qinggangshu Village}

Through the material carding including field investigation, interviews and historical data, it was found that the Qinggangshu Village population was an outflow state before the construction of the new village in recent years. Although Qinggangshu Village had a good natural and cultural environment, most young people preferred to seek a better life by working in the city rather than staying in their hometown to engage in farm production. Thus, the vitality of the village was gradually hollowed out, which is the essence of the current situation of most rural areas in China [49]. The fundamental cause of the problem is that the village development state can't effectively support the villagers' material needs for a good life, which is an important reason in the decline of the countryside [50,51]. The traditional development mode of Qinggangshu Village had the following problems before 2012:

(1) Having no leading industry

Qinggangshu Village relied mainly on traditional agricultural planting to develop the rural economy. Individual, small and scattered farming types were the major forms of agricultural production. Traditional agriculture of Qinggangshu Village lacked a scale effect and technological support, resulting in a low agricultural income. Low income made most young people unwilling to stay in the village to engage in agricultural production. Additionally, the village lacked a rural collective economy, which is an effective economic support in promoting rural development [52]. The family production and management mode made the production factors lack linkages, with the production relationship unable to effectively adapt to the productive forces. As a result, large areas of land were idle, and the economic development of Qinggangshu Village was stagnant.

(2) Imperfect infrastructures

Although Qinggangshu Village had superior natural conditions, the production, life and landscape were independent. Villagers of Qinggangshu Village lived dispersedly (Figure 9). Qinggangshu Village lacked basic ancillary facilities, and the roads had a poor connectivity between different production groups. The roads connecting the residential areas were mostly rural narrow roads.

(3) Crude and unexcavated landscapes

In the field investigation, it was found that, prior to 2012, the native environment of the village had been well preserved, but the villagers' local consciousness was weak, the natural landscape and the humanistic landscape had a lack of effective arranging, and some of the cultural heritage was ignored and deserted (Figure 10). Natural landscape features of Qinggangshu Village were also blurred and forgotten. The wild weeds in the village showed a mixed-indistinct landscape pattern. The traditional buildings in the village were dilapidated, while the new buildings abruptly contrasted with the traditional buildings.

From a comprehensive view, no leading industry, imperfect infrastructures, and crude and unexcavated landscapes result in Qinggangshu Village being in a state of decline. 


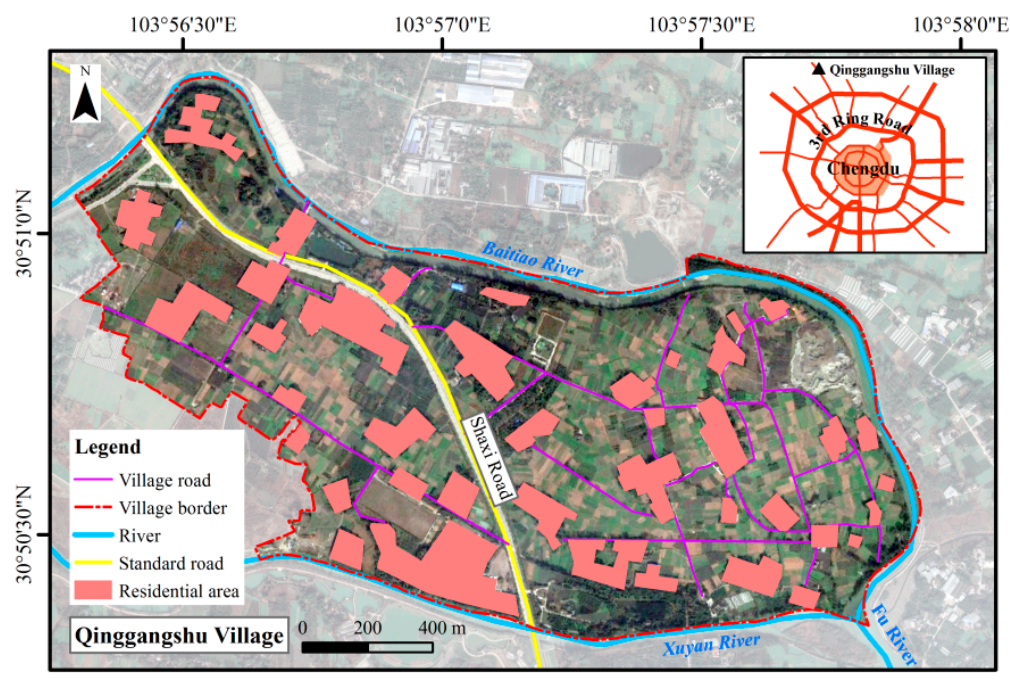

Figure 9. Sparsely distributed residential areas and rough village roads in 2010.
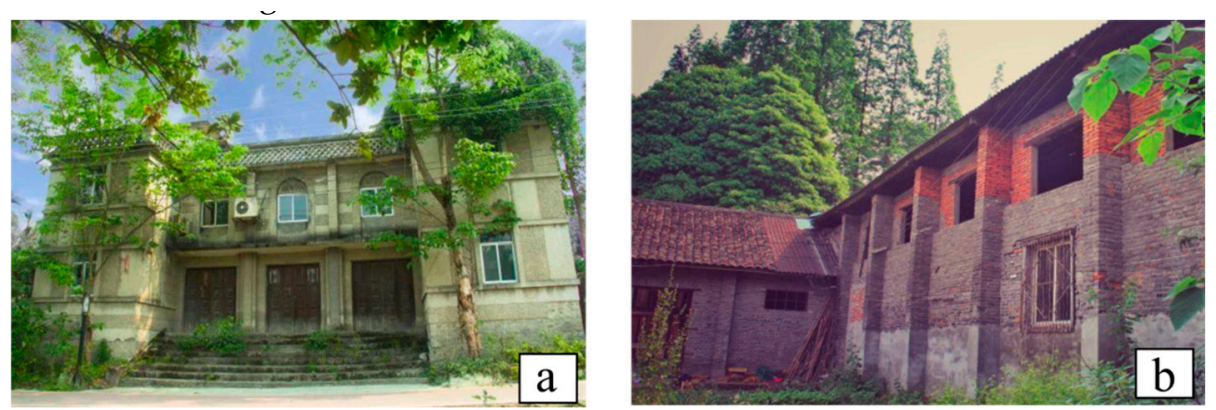

Figure 10. Old cinema landscape of Qinggangshu Village, (a) A front view of the old cinema; (b) A lateral view of the old cinema.

\subsubsection{AMD Model Based on the Integrated Development Mode of "Production, Village and Landscape"}

As seen in the situation of Qinggangshu Village, the foundation for the sustainable development of the village lies in the use of the advantageous resources in guiding rural construction according to local conditions. In view of the real problems such as strong labor outflow, weak industrial base and backward infrastructures in the village, the primary task is to increase the income of the farmers and attract the return of the labor force. Secondly, by maximizing the use of existing agricultural resources, developing the characteristic agriculture, and integrating the "production, village and scenery" in a friendly environment, production space could be symbiotic, living space could be harmonious and comfortable, and the ecological space could be sustainable.

The integrated planning of "production, village and scenery" in Qinggangshu Village is the development according to local rural conditions. The integrated development mode of "production, village and scenery" in Qinggangshu Village can be divided into three levels, namely, Aims, Measures and Demands, which can be named the rural tourism AMD development model (Figure 11). This model takes into account the rural situation and combines various elements of rural development together [35]. 


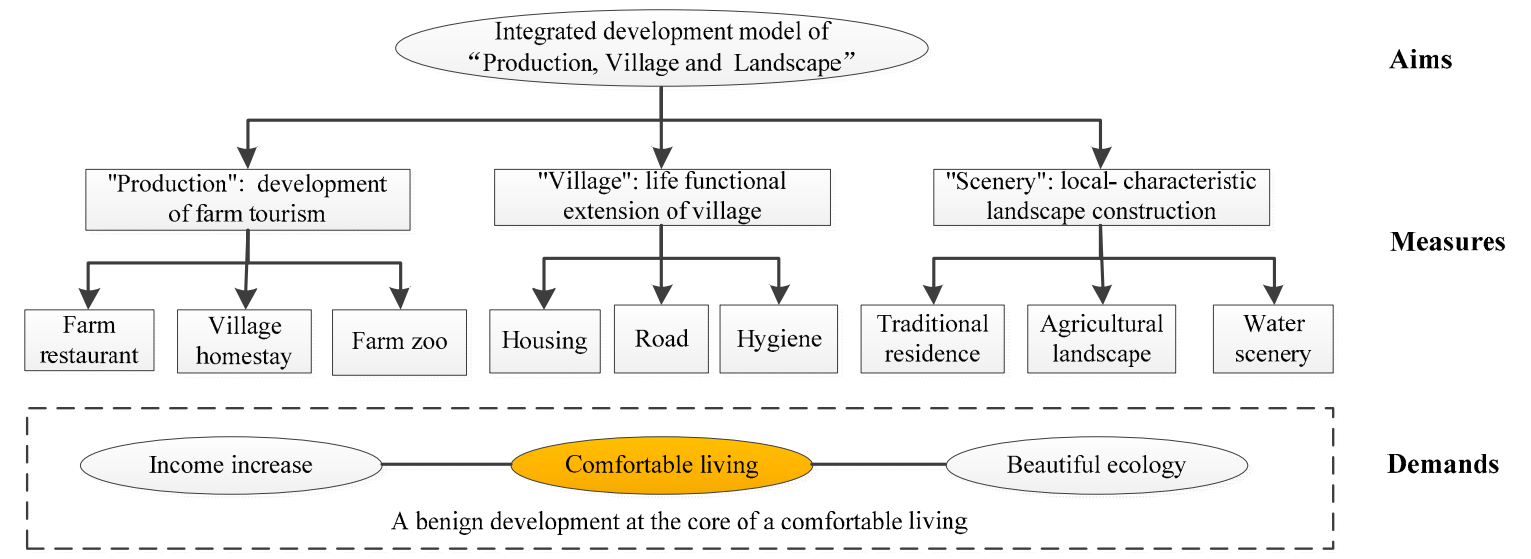

Figure 11. "Production, village and scenery" of the AMD model in Qinggangshu Village.

1. Village planning to construct livable environment.

In 2012, Qinggangshu Village was brought into the "group micro life" demonstration village project by Pixian County. The construction of the new Qinggangshu Village focused on the change of land use. Originally, the area of per-capita construction land in the village was up to 170 square meters. Through the land renovation, scattered and idle collective-construction land in the village was reclaimed. As a result, the per-capita construction land reduced from 170 square meters to 70 square meters. More land was being used centrally, of which 0.14 square kilometers of land was used to build new houses and infrastructure facilities, 0.18 square kilometers were put into the market for the exchange of capital, and 0.01 square kilometers of land was reserved by the village for the development of collective industry. The new village of Qinggangshu adhered to the "small scale, group type, micro field and ecology" model. Every twenty or thirty households were concentrated, the landscape and roads were interlaced, and nine large new courtyards had been formed (Figure 12). Village regrouping is an effective way to revitalize the countryside [53]. As a result of village regrouping, Qinggangshu Village has made the use of land more effective.

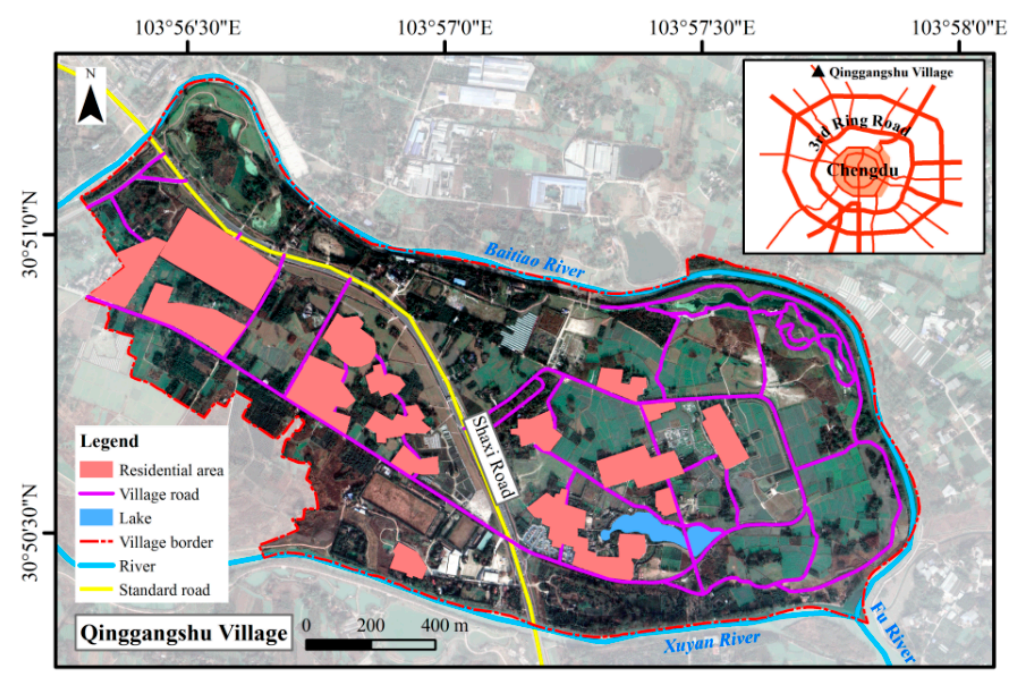

Figure 12. Replanning the settlements and roads of Qinggangshu Village.

The building of the new village inherits the characteristic brick and tile structure of Western Sichuan, which transforms the surrounding environment into a small closed environment, displaying a harmonious unity between people, housing, and the environment [54]. There are fruit trees and flowers at the front and back of the houses (Figure 13a), forming beautiful pastoral scenery. The management 
company has hired some villagers as staff members, including law enforcement officers and cleaning personnel (Figure 13b).
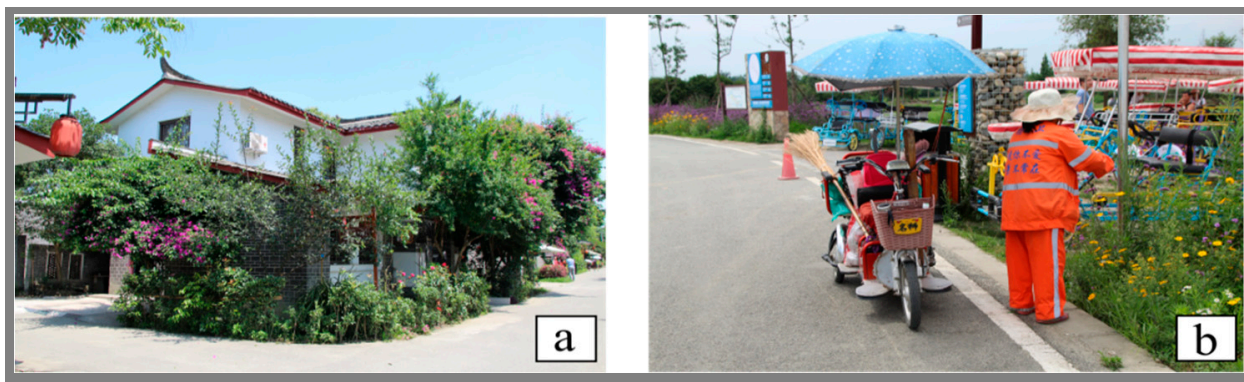

Figure 13. Improvement of living environment, (a) House; (b) Road cleaning.

2. Tourism development to create vitality for villages

Capital gained from selling the land use agreements was used to build new homes for residents. The villager's original homestead area and housing construction were exchanged for new houses in accordance to certain rules. The villagers were given new houses without spending money, which is one of the successful phases in the construction of Qinggangshu Village. This part of the capital had also become an important fund for the establishment of the Vanilla Lake Tourism Company (Figure 14). Compared with the unplanned and aimless rural tourism development, the establishment of tourism companies can better guide the development of local rural tourism $[55,56]$.

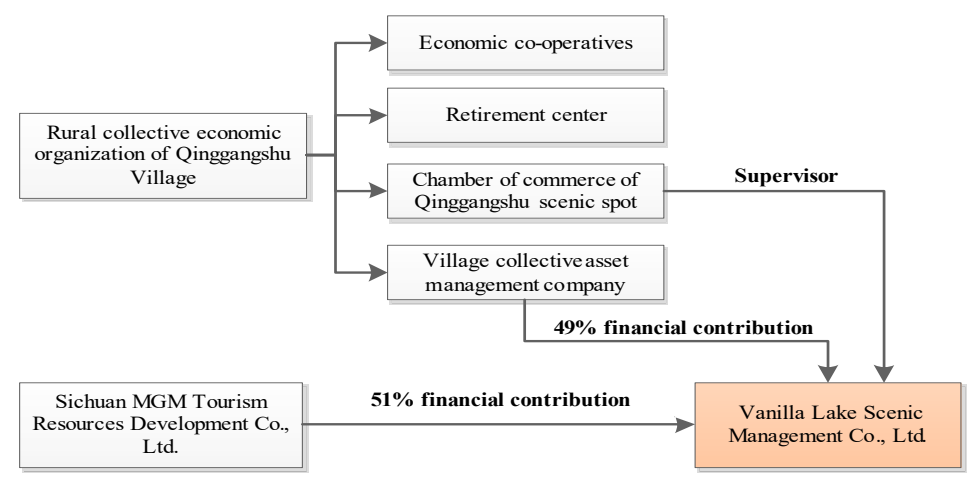

Figure 14. Establishment of a tourism management company in Qinggangshu Village.

After the construction of the new Qinggangshu Village was finished, the beautiful scenery attracted surrounding residents to come and experience it. In the early stage of the tourism development, most of the central villagers or those near the main road used their own houses to take part in the tourism, and a small number of residents in Qingganshu Village transformed their houses into tea houses, farm restaurants (Figure 15a), village homestays and a farm zoo (Figure 15b). In the later stage, the number of villagers participating in tourism management increased continuously. These measures contributed to the increased income of the villagers. 

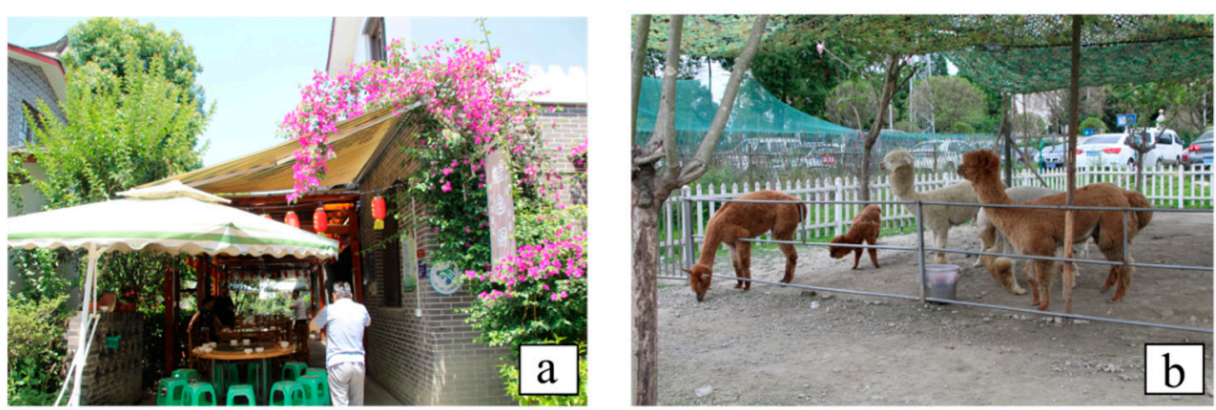

Figure 15. Industrial development of Qinggangshu Village: (a) Farm restaurant; (b) Farm zoo.

3. Landscape construction to make the village more beautiful

Beautiful rural scenery needs continuous management and capital investment, and then the promotion of the development of rural tourism [56,57]. The management company of Qinggangshu Village has hired villagers to grow rape and rice, create agricultural landscapes, or pull grass in villages to maintain the village landscapes. The Vanilla Lake (Figure 16a) is an important landscape in the village of green bars. The radial area centered around Vanilla Lake is cherished by tourists (Figure 16b-d).
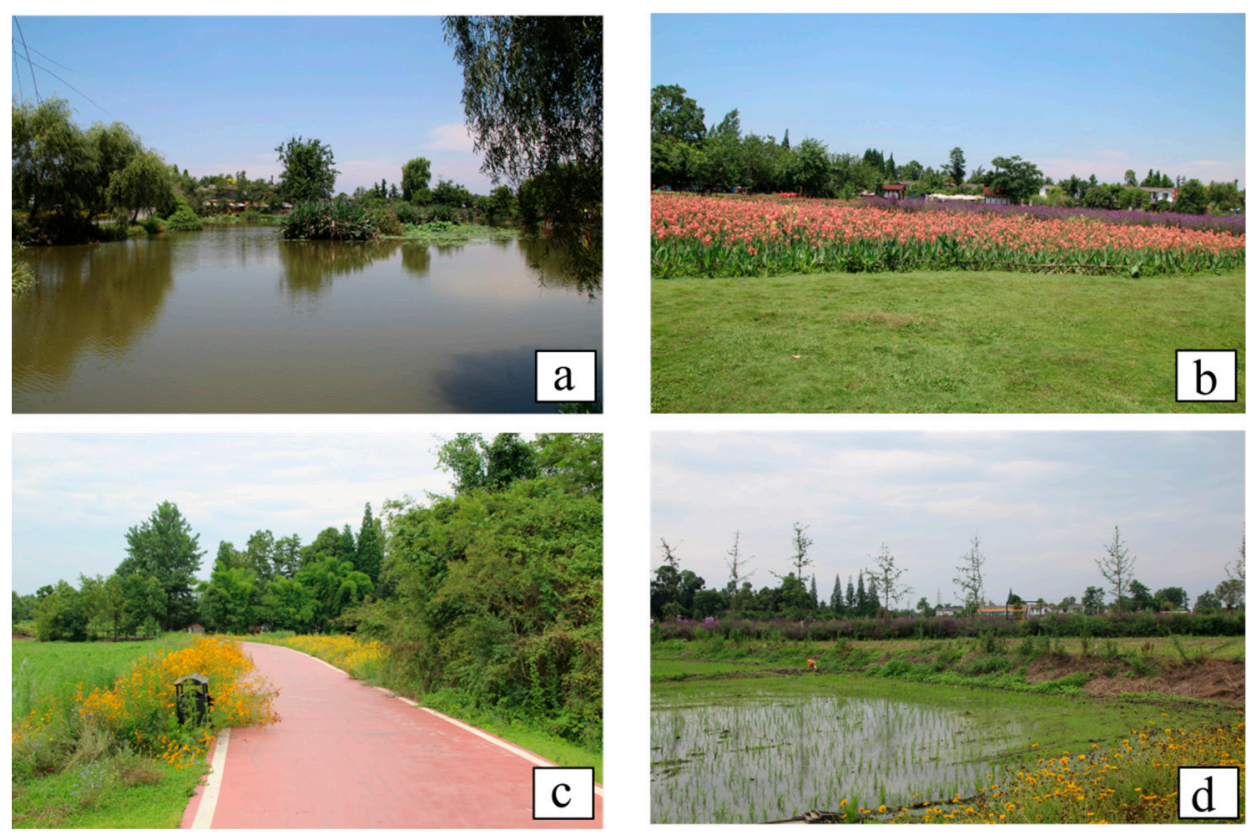

Figure 16. Landscape construction, (a) The Vanilla Lake; (b) Flower planting; (c) Footpath; (d) Farmland landscape.

\section{Discussion}

China's rapid urbanization and industrialization process has resulted in a large consumption of natural resources, widening the poverty gap between regions and societies, and serious environmental pollution [58-60]. This development mode requires change in order to avoid potentially huge risks and multiple challenges [61]. In recent years, tourism as an environment-friendly industry has become the driving force for economic and social development in developed and developing countries, especially in rural revitalization and poverty alleviation, which show the value of sustainability [62].

Due to differences in political and economic aspects between different countries and regions, as well as the different degrees of participation from the state and local governments in rural construction, rural construction and developments have their own characteristics [12-15]. The research objective 
was to take the 50 most beautiful villages, as identified by the Ministry of Agriculture, in five batches. This study used Geographic Information System (GIS) spatial analysis technology to analyze their spatial distribution characteristics from the perspective of regional differences and reveals the influencing factors. It was found that the spatial distribution of beautiful countryside in China has significant regional differences, with more in the East and less in the West. During the development of rural industry, tourism-oriented villages accounted for the most $(76 \%)$, which is closely related to the sustainable development of rural policy pursued by the government in recent years [24-27].

However, beautiful village construction is a typical example of China's rural revitalization strategy and is an important way to promote rural economic development, yet it is not the only way. The construction of beautiful villages in China has effectively prevented the widening gap between urban and rural areas and alleviated the social crisis $[63,64]$, but has not fundamentally established a benign interaction mechanism between urban and rural areas. In light of the fact that Chinese villages are going through issues of declining and hollowing [65-67], the government should play a leading role and complete the planning of rural revitalization according to local conditions. We should fully rely on the sustainable advantages of rural nature, traditional farming culture and ecology, as well as vigorously change the predicament of rural development in poor western provinces and reshape the sustainable development function of rural areas.

\section{Conclusions}

Rural tourism is the engine of rural economic and social development under the strategy of rural revitalization. Only by pursuing sustainable effects can we achieve comprehensive results and follow-up value. Based on the analysis of 50 Beautiful Villages in China, this paper takes Qinggangshu Village in Chengdu, Sichuan, as a case study, and focuses on the analysis of the rural tourism integrated development mode of the "production, village, and landscape" based on the AMD development model. In comparison with the single rural development mode in the past, the integrated development mode considers the happiness of residents, prosperity of industry and beautiful environment as the criteria with which to evaluate the rural community construction. Different development modes have different impacts on villages. Rural revitalization is an effective way to solve the rural decline problem. In the traditional development of countryside, economic development is put first. The result is that even if the rural economy realizes development, the rural environment and the living environment may be damaged. The practice of the Beautiful Village Project shows that under the stimulation of rural tourism, the rural area is no longer a simple material space but a social space with economic value. Therefore, in the process of revitalizing the village, we should not blindly pursue economic benefits but, according to the regional resource endowment, promote it from the aspects of industry, landscape and village.

Rural areas are the cornerstones of human development, and the development of rural areas is closely related to the development of the whole society [68,69]. Qinggangshu Village is a typical beautiful village and its development model is very representative. In the future, more villages will be revitalized by developing tourism, and the AMD model of Qinggangshu Village will provide a good reference for the development of other villages. To gain further understanding and find an appropriate way to achieve rural revitalization, the subsequent research will follow up the spatial production process of Qinggangshu Village and explore the reasonable and perfect rural development model more deeply.

Author Contributions: C.G. and L.C. designed the method, conceived the experiments. J.I., D.C. analyzed the data; and C.G., L.C., J.I. and D.C. wrote the paper.

Funding: This research was supported by the special funds for basic scientific research services of the Central University (No. 2012017yjsy137), the Ministry of Culture and Tourism project (No. 18TACG006), the National Natural Science Foundation (No. 40971297), the major project of Sichuan social science research planning (No. SC16ZD08) and the Innovation Spark Project of Sichuan University (2018hhs -57), the Regional History and Frontier Studies of Sichuan University. 
Conflicts of Interest: The authors declare no conflict of interest.

\section{References}

1. Yang, R.; Liu, Y.; Long, H.; Zhang, Y. Research progress and prospect of rural transformation and reconstruction in China: Paradigms and main content. Prog. Geogr. 2015, 34, 1019-1030.

2. Ploeg, J.D.V.D.; Renting, H.; Brunori, G.; Knickel, K.; Mannion, J.; Marsden, T.; Roest, K.D.; Sevilla-Guzmán, E.; Ventura, F. Rural development: From practices and policies towards theory. Sociol. Rural. 2010, 40, $391-408$. [CrossRef]

3. Marsden, T.; Banks, J.; Renting, H.; Van Der Ploeg, J.D. The road towards sustainable rural development: Issues of theory, policy and research practice. J. Environ. Policy Plan. 2010, 3, 75-83. [CrossRef]

4. Torre, A.; Wallet, F. Conclusion. Rural Development in the 21st Century; Springer International Publishing: Berlin/Heidelberg, Germany, 2016.

5. Arabatzis, G.; Aggelopoulos, S.; Tsiantikoudis, S. Rural development and leader+in Greece: Evaluation of local action groups. J. Food Agric. Environ. 2010, 8, 42-55.

6. Markey, S.; Halseth, G.; Manson, D. Challenging the inevitability of rural decline: Advancing the policy of place in northern British Columbia. J. Rural Stud. 2008, 24, 409-421. [CrossRef]

7. Curry, N. Sustainable rural development in England: Policy problems and equity consequences. Local Economy 2012, 27, 95-102. [CrossRef]

8. Owen, D.; Hogarth, T.; Green, A.E. Skills, transport and economic development: Evidence from a rural area in england. J. Transp. Geogr. 2012, 21, 80-92. [CrossRef]

9. Woods, M.; Woods, M. Rural geography: Processes, responses and experiences in rural restructuring. Rural Geogr. Process. Responses Exp. Rural Restruct. 2005, 7, 494-496.

10. Woods, M. Contesting Rurality: Politics in the British Countryside; Routledge: London, UK, 2017.

11. Rullière, G.; Tracy, M. Agriculture in western Europe, crisis and adaptation since 1880. Econ. Hist. Rev. 1964, 18, 78-82. [CrossRef]

12. Gray, J. The common agricultural policy and the re-invention of the rural in the European community. Sociol. Rural. 2000, 40, 30-52. [CrossRef]

13. Childs, G.; Minay, C. The Northern Pennines Rural Development Board: A Rural Development Agency in Theory and Practice; Oxford Polytechnic, Department of Town Planning: Oxford, UK, 1977.

14. Ohara, K.; Soda, O. The development of agriculture and agricultural policy and the change of views on farming and rural society after world war II [in Japan]. Bull. Fac. Bioresour. 1994, 12, 167-181.

15. Ranson, B. Rural education and economic development in China, Mexico, Japan, and the united states. Comp. Educ. Rev. 1988, 32, 213-225. [CrossRef]

16. Knight, J. Rural revitalization in japan: Spirit of the village and taste of the country. Asian Surv. 1994, 34, $634-646$. [CrossRef]

17. Mcmorran, C. Anthony rausch, cultural commodities in Japanese rural revitalization: Tsugaru nuri lacquerware and tsugaru shamisen. Brill, 2010, 200pp. Asian J. Soc. Sci. 2011, 39, 553-555. [CrossRef]

18. Wahlin, W.; Natsuda, K. One village one product: Japan's rural entrepreneurial scheme goes abroad. Japan Inc. 2008, 75, 60 .

19. Shakya, G. Understanding one Village one Product in Japan, Thailand and Nepal; Agro Enterprise Centre/Japan International Cooperation Agency (JICA), Nepal office: Kathmandu, Nepal, 2011.

20. Thu, N.T.A. One village one product (ovop) in Japan to one tambon one product (otop) in Thailand: Lessons for grass root development in developing countries. J. Soc. Dev. Sci. 2013, 4, 529.

21. Pinkston, D.A. The evolution of south Korea's rural institutions: The political economy of export promotion and market protection. J. East Asian Stud. 2007, 7, 61-92. [CrossRef]

22. Shi, L. A search for "alternative" developmental paradigm: New village movement in South Korea and rural \construction in China. Sociol. Res. 2004, 4, 39-49.

23. Williams, W.M. Changing functions of the community. Sociol. Rural. 2008, 4, 299-314. [CrossRef]

24. Zou, L.X. Research on rural revitalization strategy in China. Sci. Decis. Mak. 2017, 12, 19-34.

25. Liu, Y.; Li, Y. Revitalize the world's countryside. Nature 2017, 548, 275-277. [CrossRef] [PubMed]

26. Zhu, Q. Obstacles to the rural rejuvenation and solutions. Frontiers 2018, 3, 19-25. 
27. He, Y.; Sun, P.; Chai, Z. Village planning methods based on the holistic concept of landscape. City Plan. Rev. 2012, 36, 58-62.

28. Pan, L.; Shan, T.; Tang, Z. Urban layout research base the integration theory of production, life and ecology: Wenzhou example. Planners 2014, 3, 265-270.

29. Zheng, X.Q.; Chen, M. Theoretical framework and model design for beautiful countryside construction in china. J. Agric. Resour. Environ. 2015, 32, 106-115.

30. Cheng, Y. Research on the consumption space production of community-type scenic areas based on the observation of Hong village in Anhui province. In Proceedings of the International Conference on Judicial, Administrative and Humanitarian Problems of State Structures and Economic Subjects, Moscow, Russia, 21-23 September 2017.

31. Kloog, I.; Haim, A.; Portnov, B.A. Using kernel density function as an urban analysis tool: Investigating the association between nightlight exposure and the incidence of breast cancer in Haifa, Israel. Comput. Environ. Urban Syst. 2009, 33, 55-63. [CrossRef]

32. Zuo, Z.; Liu, Y.; Chen, B.; Chen, K. Using Gis and Kde Analysis Spatial Distribution on Public Housing Households: A Case Study; IEEE: Piscataway, NJ, USA, 2013.

33. Cui, Y.; Cheng, D.; Choi, C.E.; Jin, W.; Lei, Y.; Kargel, J.S. The cost of rapid and haphazard urbanization: Lessons learned from the freetown landslide disaster. Landslides 2019, 16, 1-10. [CrossRef]

34. Cheng, D.; Cui, Y.; Su, F.; Jia, Y.; Choi, C.E. The characteristics of the Mocoa compound disaster event, Colombia. Landslides 2018, 15, 1223-1232. [CrossRef]

35. Gao, C.; Cheng, L.; Cheng, D. Research on rural integration development mofe base on integration of production, village and scenery: Take an example from daigou' s integrated practice. Issues Agric. Econ. 2019, 5, 90-97.

36. Xie, B.; Xiang, Y. Construction and application of evaluation index system for beautiful China. Econ. Geogr. 2017, 37, 15-20.

37. Liu, Y. Research on the urban-rural integration and rural revitalization in the new era in China. Acta Geographica Sin. 2018, 73, 637-650.

38. Kong, J.; Fu, M. Research on characteristics of spatial form of the natural resources type tourism villages-Based on China's top ten most beautiful villages. Archit. Cult. 2015, 12, 155-156.

39. Ministry of Agriculture and Rural Affairs of the People's Republic of China. Most Beautiful Villages in China. Available online: http://www.moa.gov.cn/ (accessed on 13 June 2019).

40. Strategy, D.F. Do People with Tibetan Plots Know All These Places? Available online: http://www.sohu.com/ a/167842125_628049 (accessed on 13 June 2019).

41. Roadside, A.T. Finding Nahui Village, Guizhou Province, the Beautiful Village in China. Available online: http://k.sina.com.cn/article_6440809460_17fe6f3f40010043hv.html?from=travel (accessed on 13 June 2019).

42. Eraqi, M.I. Rural tourism quality: Fayoum as a rural tourist destination in Egypt. Int. J. Tour. Anthropol. 2010, 1, 70-86. [CrossRef]

43. Wang, S.W.; Wang, J.L.; Wang, H. Influence of foreign garbage to ecological environment in China and analysis on the risk management and control of customs. China Popul. Resour. Environ. 2016, 26, 22-31.

44. Wang, C.; Yang, Y.; Zhang, Y. Economic development, rural livelihoods, and ecological restoration: Evidence from China. Ambio 2011, 40, 78-87. [CrossRef] [PubMed]

45. Xing, X.F. Measurement and analysis of the relationship between economic development and environmental protection of Shandong province. China Popul. Resour. Environ. 2006, 16, 58-61.

46. Jiang, J.B.; Wu, X.X.; Lu, Y. Towards a better understanding of the relationships between tourism involvement and place attachment: Evidence from rural tourism destinations in China. Int. J. Tour. Anthropol. 2014, 3, $245-260$. [CrossRef]

47. Vajirakachorn, T.; Nepal, S.K.; Su, M.M. Local perspectives of community-based tourism: Case study from Thailand's Amphawa floating market. Int. J. Tour. Anthropol. 2014, 3, 342-356. [CrossRef]

48. Wang, Y.; Liu, J.; Xue, H.; Tan, Z. Rural plan implementation based on land property right innovation: A case study on Qinggangshu village in Chengdu. Dev. Small Cities Towns 2018, 27, 34-41.

49. Hu, S.; Liu, Y.; Xu, K. Hollow villages and rural restructuring in major rural regions of China: A case study of Yucheng city, Shandong province. Chin. Geogr. Sci. 2011, 21, 354-363.

50. Hu, B.; Chen, C. New urbanisation under globalisation and the social implications in China. Asia Pac. Policy Stud. 2015, 2, 34-43. [CrossRef] 
51. Wang, Y.; Xin, L.; Zhang, H.; Li, Y. An estimation of the extent of rent-free farmland transfer and its driving forces in rural China: A multilevel logit model analysis. Sustainability 2019, 11, 3161. [CrossRef]

52. Chen, A. The politics of the shareholding collective economy in China's rural villages. J. Peasant Stud. 2016, 43, 828-849. [CrossRef]

53. Li, X.; Liu, Y.; Chen, Y.; Li, P.; Yu, Z. Village regrouping in the eastern plains of China: A perspective on home-field distance. Sustainability 2019, 11, 1630. [CrossRef]

54. Yunzhang, L.; Xukun, L.; Yi, C. Comparative study of the street space of the western of Sichuan and Huizhou folk houses. Huazhong Archit. 2015, 6, 176-180.

55. Bagur-Femenías, L.; Perramon, J.; Oliveras-Villanueva, M. Effects of service quality policies in the tourism sector performance: An empirical analysis of Spanish hotels and restaurants. Sustainability 2019, 11, 872. [CrossRef]

56. Fotiadis, A.; Nuryyev, G.; Achyldurdyyeva, J.; Spyridou, A. The impact of EU sponsorship, size, and geographic characteristics on rural tourism development. Sustainability 2019, 11, 2375. [CrossRef]

57. Zhang, T.; Chen, J.; Hu, B. Authenticity, quality, and loyalty: Local food and sustainable tourism experience. Sustainability 2019, 11, 3437. [CrossRef]

58. Yang, X.J. China's rapid urbanization. Science 2013, 342, 310. [CrossRef]

59. Poel, E.V.; O'Donnell, O.; Doorslaer, E.V. Is there a health penalty of China's rapid urbanization? Health Econ. 2012, 21, 367-385. [CrossRef]

60. Ellen, V.D.P.; O'Donnell, O.; Van Doorslaer, E. The health penalty of China's rapid urbanization. Soc. Sci. Electron. Publ. 2009, 3, 9-16.

61. Yu, A.T.W.; Wu, Y.; Zheng, B.; Zhang, X.; Shen, L. Identifying risk factors of urban-rural conflict in urbanization: A case of China. Habitat Int. 2014, 44, 177-185. [CrossRef]

62. Blancas, F.J.; Lozano-Oyola, M.; González, M.; Guerrero, F.M.; Caballero, R. How to use sustainability indicators for tourism planning: The case of rural tourism in Andalusia (Spain). Sci. Total Environ. 2011, 412, 28-45. [CrossRef] [PubMed]

63. Liu, Y.S.; Yang, Z. Challenges and countermeasures for beautiful countryside construction in China. J. Agric. Resour. Environ. 2015, 32, 97-105.

64. Chi, Z.X.; Huang, M.; Zhao, H.T. Theoretical foundation and advantageous conditions for constructing beautiful countryside in China: A case study of Jiangxi province. J. Agro For. Econ. Manag. 2015, 14, 84-90.

65. Zhou, Z.Z. Landscape changes in a rural area in China. Landsc. Urban Plan. 2000, 47, 33-38.

66. Benjamin, D.; Brandt, L.; Fan, J.Z. Ceaseless Toil? Health and Labor Supply of the Elderly in Rural China; Working Paper No. 579; William Davidson Institute: Ann Arbor, MI, USA, 2003. [CrossRef]

67. Li, Y.; Westlund, H.; Zheng, X.; Liu, Y. Bottom-up initiatives and revival in the face of rural decline: Case studies from China and Sweden. J. Rural Stud. 2016, 47, 506-513. [CrossRef]

68. Maria, G. Home away from home: landscape as a mediator between place and belonging in the peripheral areas of the Marche region in Italy. Int. J. Tour. Anthropol. 2018, 6, 340-356.CrossRef]

69. Nikolaos, B. Rural tourism and residents' well-being in Cyprus: Towards a conceptualised framework of the appreciation of rural tourism for islands' sustainable development and competitiveness. Int. J. Tour. Anthropol. 2019, 7, 60-68CrossRef]

(C) 2019 by the authors. Licensee MDPI, Basel, Switzerland. This article is an open access article distributed under the terms and conditions of the Creative Commons Attribution (CC BY) license (http://creativecommons.org/licenses/by/4.0/). 